\title{
Four decades of foraging history: stock-specific variation in the carbon and nitrogen stable isotope signatures of Alaskan sockeye salmon
}

\author{
Susan P. Johnson*, Daniel E. Schindler \\ University of Washington School of Aquatic and Fisheries Sciences, University of Washington, Box 355020, Seattle, \\ Washington 98195, USA
}

\begin{abstract}
Broad-scale shifts in climate during the 20th century had large effects on the ecology of the North Pacific Ocean, including a substantial change in the composition of the dominant food web. Salmon production in Alaskan stocks increased with a concurrent shift of the Pacific Decadal Oscillation in 1977. Salmon production has since been persistently high through 2010, yet the biological mechanisms for this increase in production remain unclear. Carbon and nitrogen stable isotopes of sockeye salmon scales collected from 8 rivers in Bristol Bay between 1964 and 2003 were analyzed to assess whether the trophic ecology of these fish changed systematically over this period, during which there were substantial changes in oceanographic conditions. Isotope values were remarkably stable over the study despite substantial changes in salmon production and oceanographic conditions in this region. Our results also suggest river-specific patterns in the variation of stable isotopes through time; stable isotope changes were related to stock identity and showed some geographic organization. Larger salmon tended to have depleted $\delta^{15} \mathrm{~N}$ and $\delta^{13} \mathrm{C}$. Isotopic characteristics among rivers became more variable during the period of high ocean productivity (after the 1977 regime shift and before the 1989 regime shift). Some of the dominant signals of variation in stable isotope variation were related to important environmental physical processes, but they appear to have unique effects on the isotopic characteristics of stocks from different rivers, suggesting important connections between the ecology of sockeye salmon in freshwater and in the ocean.
\end{abstract}

KEY WORDS: Climate $\cdot$ Trophic ecology $\cdot$ Biocomplexity $\cdot$ Food web $\cdot$ North Pacific Ocean $\cdot$ Pacific Decadal Oscillation

Resale or republication not permitted without written consent of the publisher

\section{INTRODUCTION}

Widespread ecological changes have been observed in the sub-arctic domain of the North Pacific Ocean over the last 4 decades (e.g. Pearcy \& Schoener 1987, Anderson \& Piatt 1999). Much of the biota of the North Pacific and Bering Sea was affected by shifts in climate, including changes in abundance of zooplankton, salmon and groundfish (Hare \& Mantua 2000). One of the more notable changes included a reorganization of the food web structure in the Gulf of Alaska and the Bering Sea from one dominated by crustaceans and capelin Mallotus villosus to one dominated by several species of groundfish such as walleye pollock Theragra chalcogramma (Anderson \& Piatt 1999, Conners et al. 2002). This major food web reorganization occurred concurrently with a shift to a warm or positive phase of the Pacific Decadal Oscillation (PDO) in 1977 and a weaker regime shift to more moderate conditions in 1989 (Hare \& Francis 1995, Mantua et al. 1997, Hare \& Mantua 2000), yet most of the biological and physical mechanisms producing the changes in the food webs of the North Pacific associated with shifts in the PDO remain obscure. 
Changes in the climate regime during the mid1970s were also associated with large-scale changes in Pacific salmon (Oncorhynchus spp.) production (Mantua et al. 1997). Climate forcing, as captured by PDO dynamics, is correlated with salmon production such that small changes in the physical environment, such as nearshore warming and offshore cooling in the ocean, translated into substantial changes in fisheries production (Mantua et al. 1997). In addition, there was geographic organization in the responses of salmon production to climate change. Pacific salmon production in Alaska increased sharply after the late 1970s but declined substantially in Canada and the Pacific Northwest (Mantua et al. 1997, Hare et al. 1999). Although several studies have modeled variation in marine food webs in response to climate change that affects salmon survival (e.g. Francis et al. 1998, Beamish et al. 1999, Aydin et al. 2005), there has been little assessment of the patterns of marine salmon foraging in relation to climatic variation over the periods encompassing the major food web reorganization associated with shifts in the PDO. Thus, the linkages between changes in climate forcing variables, oceanographic conditions and the trophic ecology of Pacific salmon remain poorly understood.

The term biocomplexity has been used to describe the diversity in life-history characteristics and adaptations to freshwater habitat conditions observed among different populations of sockeye salmon Oncorhynchus nerka in Bristol Bay, Alaska. This biocomplexity within the stock complex has stabilized salmon fishery production despite environmental variation resulting from changing climate conditions (Hilborn et al. 2003, Schindler et al. 2010). In some climate regimes, specific salmon stocks flourish, whereas other stocks increase in productivity during other climate regimes (Rogers \& Schindler 2011). Such weak covariation among the components of the stock complex of Bristol Bay sockeye salmon stabilizes the production from the overall ecosystem.

Salmon stocks are aggregates of locally adapted populations, each of which shows variation in biological attributes such as body size and shape. Those populations that are geographically close (within several hundred to $1000 \mathrm{~km}$ ) show some coherence in response to regional oceanographic variables such as sea surface temperature (SST) (Mueter et al. 2002, Pyper et al. 2005). However, other studies of individual populations have emphasized the diversity of responses to regional climate shifts (Hilborn et al. 2003, Rogers \& Schindler 2008, 2011, Schindler et al. 2010). Although unique population-specific biological attributes are documented extensively during the freshwater phase of the sockeye salmon life cycle (Quinn 2005), it remains essentially unknown whether these differences are also associated with the marine phase of the salmon life cycle.

Individual stocks may also use a variety of marine foraging and migration strategies that further enhance the success of stock complexes as a whole. Salmon may have stock-specific spatial distributions in the ocean (Myers et al. 2007, Habicht et al. 2010), or use different foraging strategies during the marine phase of their lives that may also produce asynchronous population responses to broad-scale changes in climate. For example, marine biocomplexity among salmon stocks may be expressed as stocks using space or prey resources differently in the ocean. Kaeriyama et al. (2004) hypothesized that salmon respond to climate-induced changes in marine prey resources by switching their diets between or within trophic levels, and Welch \& Parsons (1993) showed that stocks of sockeye salmon from British Columbia and Bristol Bay have different trophic ecologies based on stable isotope analysis. They hypothesized that these differences were due to spatial separation in ocean feeding. The understanding of differential use of ocean resources by salmon populations and the relationship to changes in climate may provide important insights relevant to conservation of population diversity and management of salmon stocks (Hilborn et al. 2003, Schindler et al. 2010). However, there has been little assessment of whether different stocks of fish from within the same freshwater region use the ocean in fundamentally different ways over time.

Stable isotope analysis of carbon (C) and nitrogen (N) can be used to characterize patterns of biogeochemistry, physiology and trophic ecology of consumers (Peterson \& Fry 1987). Stable isotope characteristics of archived tissues can provide integrated trophic histories of consumers (e.g. Satterfield \& Finney 2002, Hilderbrand et al. 1999, Vander Zanden et al. 2003, Yeakel et al. 2009). One tissue type that can be used in such analyses is fish scales, which are routinely sampled in fisheries and are easily stored and archived. Like keratinous tissues such as nails and hair, scales are metabolically inert after formation and therefore reflect the isotopic signature of when or where they were synthesized (e.g. Schell et al. 1989, Hirons et al. 2001). An entire scale reflects the isotopic signature of the diet of that particular fish over its life, although biased toward the last growing season or period when most growth was accumulated (Hutchinson \& Trueman 2006, Trueman \& Moore 2007).

Here we analyzed carbon and nitrogen stable isotope characteristics of sockeye salmon scales col- 
lected from 8 rivers in Bristol Bay between 1964 and 2003. Our goal was to determine whether the trophic ecology of these fish changed systematically over this period, during which there were substantial changes in oceanographic conditions. Specifically, we hypothesized that (1) substantial changes in the isotopic composition of sockeye salmon scales would occur concomitantly with changes in the organization of the North Pacific Ocean following the shift in the PDO in the mid-1970s and (2) these responses would be stock specific because fish from different rivers use different migration patterns throughout the marine stage of their life cycle. Production of Bristol Bay sockeye roughly doubled following the shift in the dominant mode of the PDO in 1977, but whether the diets or foraging locations of sockeye salmon from this region changed systematically at this time is unknown. We also assessed whether isotope shifts could be observed over time and whether they were correlated with changes in climate and physical oceanographic indices and salmon body size.

\section{MATERIALS AND METHODS}

Bristol Bay Alaska supports the largest sockeye salmon fishery in the world, with an average annual commercial harvest of 17 million sockeye (Clark et al.

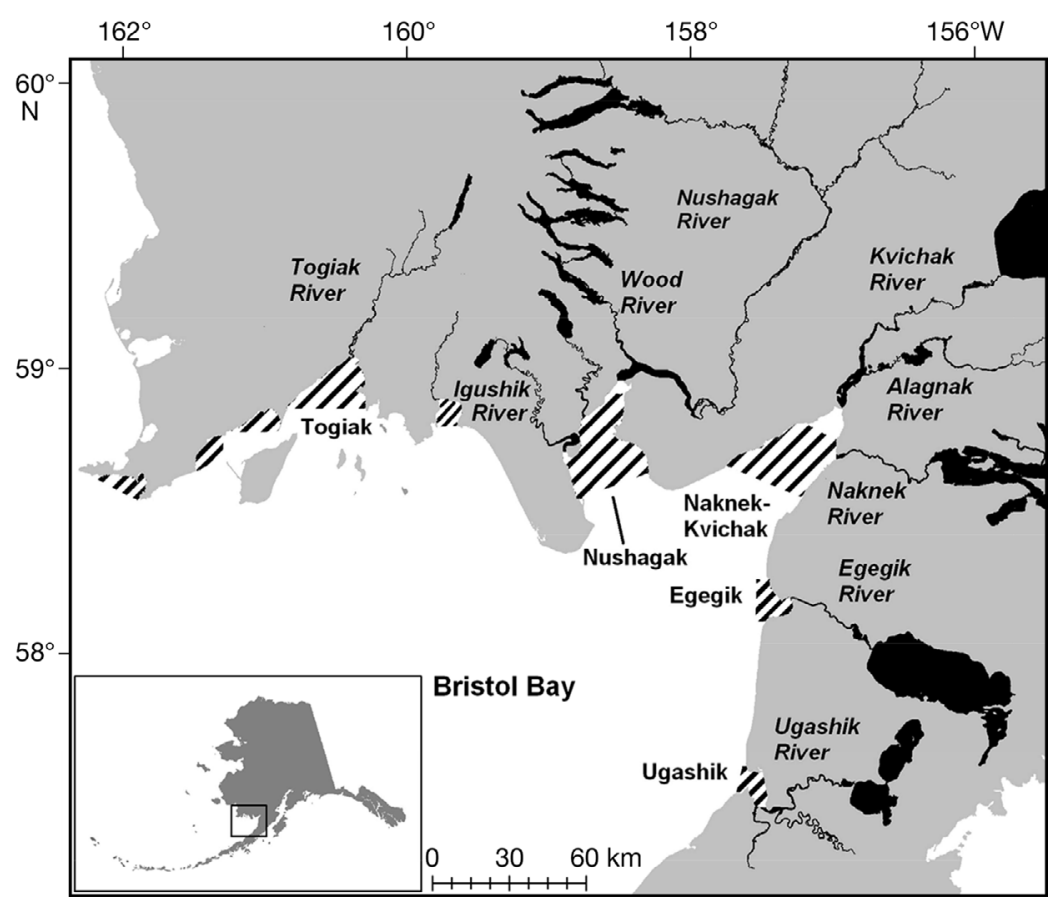

Fig. 1. Bristol Bay fishing districts and principal rivers. Fishing districts are denoted by the hatched regions
2006). In mid-June and July, homing sockeye are harvested via set and drift nets as they pass through 5 fishing districts (Ugashik, Egegik, NaknekKvichak, Nushagak and Togiak; Fig. 1) on their way to freshwater spawning habitats.

Scales archived for 40 yr (1964-2003) for rivers that comprise the major stocks of Bristol Bay sockeye salmon (Wood, Naknek, Nushagak, Kvichak, Egegik, Ugashik, Igushik and Togiak rivers) were obtained from the Alaska Department of Fish and Game (ADFG) scale archive. These scales were collected at river bank counting towers as part of the long-term monitoring program and used to establish the age composition of returning fish each year. Individual scales from 5 individual salmon were sampled every 3 yr (i.e. 1964, 1967, ..., 2003) from the sample archive of each of the 8 rivers. Sample size was chosen in an attempt to minimize the number of scales from the ADFG sample archives destroyed by stable isotope analysis while maintaining power to detect ecological relationships. All samples were from fish of the same ocean age (salmon that spent $2 \mathrm{yr}$ at sea) as determined by visual examination of scale microstructure under a dissecting microscope. Scales were removed from gummed cards and soaked in deionized water for $24 \mathrm{~h}$. Any residue was removed from the surface of scales under a dissecting microscope. Scales were thoroughly rinsed and dried prior to preparation for stable isotope analysis on whole individual scales. Nitrogen and carbon stable isotope analysis was performed at the University of Washington Oceanography Stable Isotopes Laboratory on a Finnigan Delta XL continuous-flow isotope ratio mass spectrometer (Thermo Electron Corp.). All isotopic ratios are expressed in $\delta$ notation, with units expressed as parts per thousand (\%). The standards were Vienna-Pee Dee Belemnite limestone (V-PDB) for carbon and atmospheric $\mathrm{N}_{2}$ for nitrogen. The standard deviation from repeated isotope measurements from a standard for both $\delta^{13} \mathrm{C}$ and $\delta^{15} \mathrm{~N}$ was $<0.2 \%$.

Data on potential prey items and particulate organic matter (POM) used to provide basic isotopic data for the North Pacific and Bering Sea were obtained from existing studies and unpublished data including: POM isotope data from taken in September 2001 from the Bering Sea shelf (Guo et 
al. 2004); copepod, euphausid, POM and plankton samples taken between 1997 and 1999 on the southeastern Bering Sea shelf (Smith et al. 2002); chaetognath, copepod and euphausid samples taken between 1985 and 1994 from the Bering Sea (Schell et al. 1998); and amphipod and copepod samples collected along the $180^{\circ}$ meridian in the North Pacific and Bering Sea $\left(44^{\circ} \mathrm{N}\right.$ to $\left.57^{\circ} 30^{\prime} \mathrm{N}\right)$ in June 2005 (S. P. Johnson unpubl. data).

A suite of potential atmospheric-oceanographic variables were compiled to compare with the common temporal changes observed in the stable isotope data from sockeye salmon. These variables were chosen because they have either been shown to be associated with variation in growth or production of salmon or they have known effects on the oceanographic conditions of the subarctic North Pacific Ocean. The PDO is defined as the leading principal component of the Pacific Ocean SST variability north of $20^{\circ} \mathrm{N}$ (Mantua et al. 1997). SST is a measure of May SST for the southeastern Bering Sea relative to the mean SST for the years 1961-2000 (Kalnay et al. 1996). The North Pacific Index (NPI) is the areaweighted sea level pressure over the region $30^{\circ} \mathrm{N}-$ $65^{\circ} \mathrm{N}$ and $160^{\circ} \mathrm{E}-140^{\circ} \mathrm{W}$ in the spring and is a relative measure to the mean for the years 1961-2000 (Trenberth \& Hurrell 1994). Summer wind mixing (JJmix) is measured in May in the vicinity of St. Paul Island in the Pribilofs and in the vicinity of Mooring 2 in the Bering Sea during June and July. It is measured in $\mathrm{m}^{3} \mathrm{~s}^{-3}$ and is stated relative to the mean for the years 1961-2000 (Kalnay et al. 1996). The El Niño-Southern Oscillation is a multivariate ENSO index (MEI) measured by the mean December and January values of the 6 main observed variables over the tropical Pacific (sea level pressure, zonal and meridional components of the surface wind, SST, surface air temperature and total cloudiness fraction of the sky) (Wolter \& Timlin 1998). PDO values were lagged and averaged for the $2 \mathrm{yr}$ that the fish were at sea. The other oceanographic data were lagged for $1 \mathrm{yr}$ to reflect conditions that the salmon would experience prior to the return year. PDO data were downloaded from http://jisao.washington.edu/pdo and other oceanographic data (SST, NPI, JJmix and MEI) were downloaded from www.beringclimate.noaa. gov/index.html.

\section{Statistical analyses}

Mixed-effects linear models were used to estimate the effects of site and fish length on average annual isotope values of sockeye salmon. The response variable was the isotope value averaged across individuals for a year and site. Length was the average length of sockeye for that year as measured from mid-eye to tail fork. We compared 3 models of hierarchical complexity. First, the 'base' model simply estimated an intercept and did not account for effects of site or fish length. Second, the 'site' model has the random effect of site in addition to the intercept. Finally, the 'length' model has a random effect of site and length as a fixed effect. Thus, this model estimated the slope of the relationship between length and isotope and accounted for site differences. We compared these models using Akaike's information criterion, adjusted for small sample sizes $\left(\mathrm{AIC}_{\mathrm{c}}\right)$. Lower $\mathrm{AIC}_{\mathrm{c}}$ scores indicate a better fit of the data to the model, given model complexity. We calculated $\triangle \mathrm{AIC}_{\mathrm{c}}$ as the difference between the best model and the model in question. $\triangle \mathrm{AIC}_{\mathrm{c}}$ values greater than 2 indicate a model that has substantially less support than the best model (Burnham \& Anderson 2002). AIC $_{\mathrm{c}}$ values were calculated using the 'AICcmodavg' package in R (R Core Development Team 2011).

Principal components analysis (PCA) was performed in R (R Core Development Team 2011) on carbon and nitrogen stable isotope data to extract patterns of variability that were common to all rivers through time and to reduce the dimensionality of the stable isotope data set for the 8 Bristol Bay rivers across the period of the study. PCA was run on the annual average of the 5 fish sampled from each river $x$ year combination. PC eigenvectors or loadings determine the patterns of stable isotope variability and represent the weight by which each standardized original variable must be multiplied to determine the PC score (Shaw 2003). PCA scores are the transformed values that demonstrate the temporal variability of the collection of stable isotope data $\left(\delta^{13} \mathrm{C}\right.$ or $\delta^{15} \mathrm{~N}$ over all rivers) reduced in dimensionality. Separate PCAs were run for carbon and nitrogen isotopes. We used linear models in $\mathrm{R}$ to compare how different climate and physical oceanographic data (PDO, SST, NPI, JJmix and MEI) explained the different PCA scores. As a way to compare how well the PCA were explained by 5 different oceanographic variables, we used $\mathrm{AIC}_{\mathrm{c}}$ as described above.

\section{RESULTS}

Nitrogen and carbon stable isotopes varied among rivers and across years of the study (Fig. 2, Tables A1 \& A2 in Appendix 1). Overall, nitrogen isotopes were 
more variable between rivers in a given year than carbon isotopes (Fig. 2, Table A2). Nitrogen stable isotope data were slightly more variable than carbon isotope data; however, taken as a whole, stable isotope data were remarkably similar across populations and over time (Tables A1 \& A2). Specifically, the inter-annual standard deviation (SD) for each of the rivers averaged 0.42 for $\delta^{15} \mathrm{~N}$ and 0.39 for $\delta^{13} \mathrm{C}$. Additionally, the variation observed among rivers on a given year was less for $\delta^{13} \mathrm{C}$ than for $\delta^{15} \mathrm{~N}$, resulting in a within-year SD among rivers of 0.43 for $\delta^{15} \mathrm{~N}$ and for 0.27 for $\delta^{13} \mathrm{C}$ (Fig. 3, Table A1). Available isotope data from the literature for sockeye prey and/or POM collected at different places and times show a great deal of isotope variability in the North Pacific and Bering Sea when compared with sockeye isotopes, which were less variable over the entire time period of our study (Fig. 4).

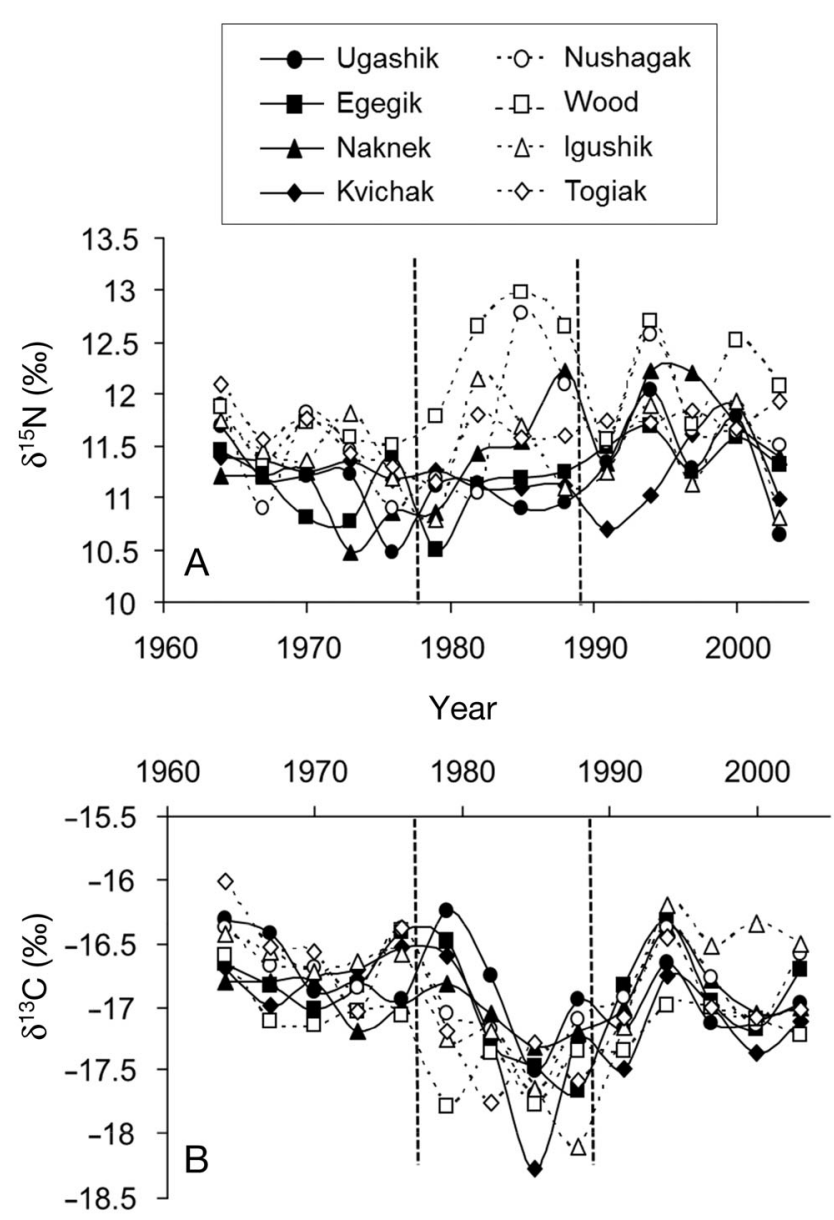

Fig. 2. (A) Nitrogen and (B) carbon stable isotope values by year. Each point is an average of 5 individual sockeye salmon. Closed symbols are east-side and open symbols are west-side rivers of Bristol Bay. Vertical dashed lines delineate regime shifts (1977 and 1989)

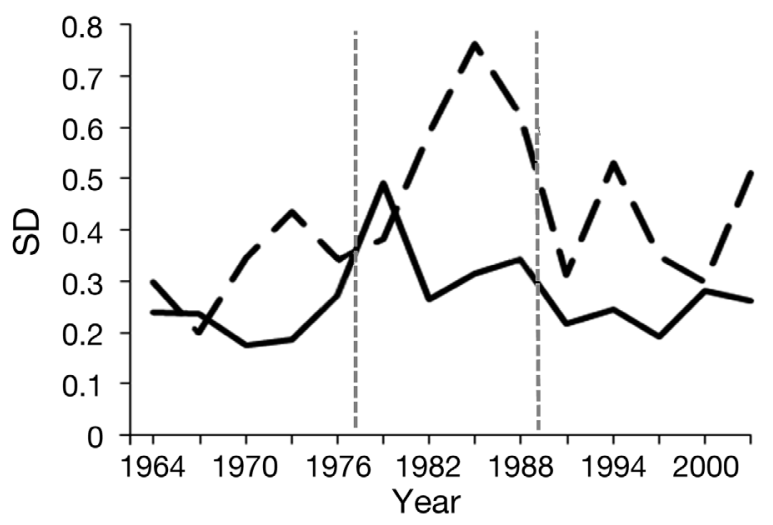

Fig. 3. Standard deviations of carbon (solid line) and nitrogen (dashed line) stable isotopes by year across all rivers. Data are based on variation across the average data among sockeye salmon sampled in a year. Gray vertical dashed lines indicate regime shifts (1977 and 1989)

\begin{tabular}{|l|l|}
\hline Schell et al. (1998) \\
Chaetognath \\
Copepod \\
Smith et al. (2002) \\
\hline$\triangle$ POM \\
$\nabla$ Net plankton \\
$\square$ Copepod \\
$\triangle$ Euphausiid \\
\hline
\end{tabular}

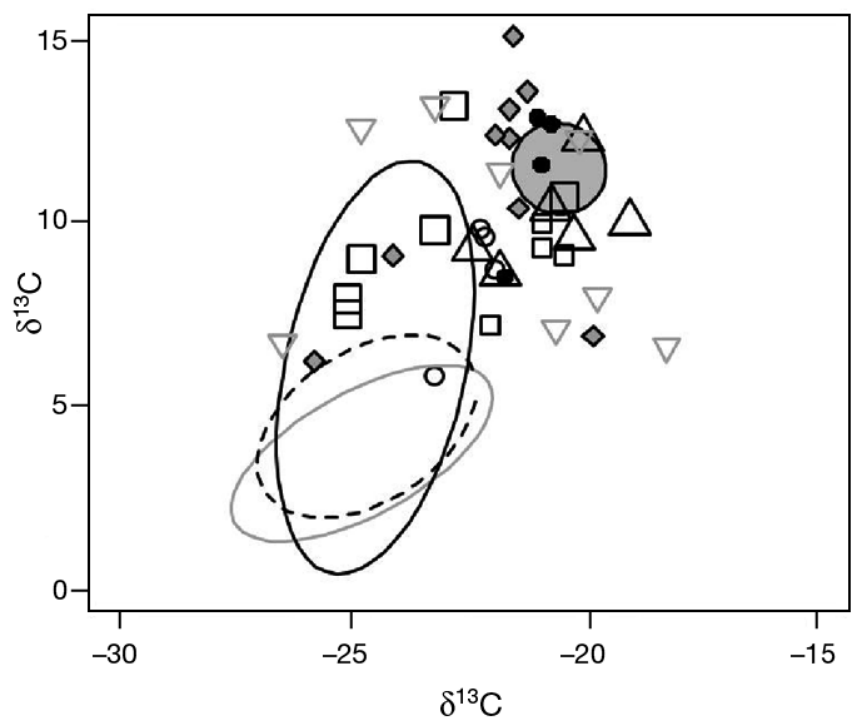

Fig. 4. Sockeye salmon prey and particulate organic matter (POM) isotope data from the literature, unpublished data and sockeye scales (present study). All data points are averages from various sample dates. If there were more than 10 sample units (different sample sites or dates), data were summarized with $95 \%$ confidence ellipses. Scale carbon isotope data were adjusted by $-3.58 \%$ to compensate for the enrichment of scale tissue (D. E. Schindler unpubl. data) to better show the relationship between sockeye and their prey 

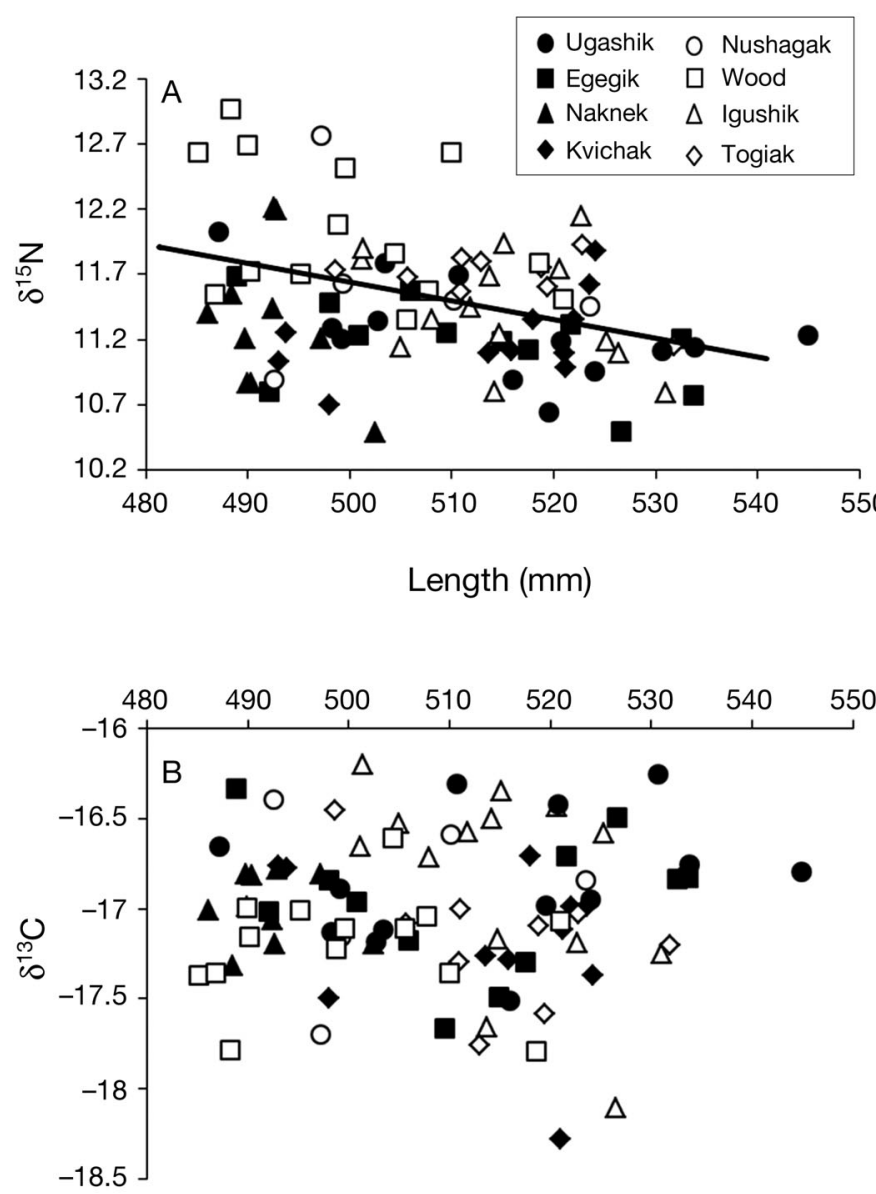

Fig. 5. Stable isotopes vs. average ocean-age-2 sockeye salmon length for each year and river that scales were sampled. (A) $\delta^{15} \mathrm{~N}$ vs. fish length. The line shows the average relationship across sites between length and $\delta^{15} \mathrm{~N}\left(\delta^{15} \mathrm{~N}=\right.$ $16.43-0.00977 \times$ length). (B) $\delta^{13} \mathrm{C}$ vs. fish length. Length only marginally improved the model describing $\delta^{13} \mathrm{C}$, thus the line is not shown

Results of model comparison of linear mixedeffects models describing the annual average isotope signatures across river systems show strong support for including length of fish in a model that also has a site effect $\left(\Delta \mathrm{AIC}_{\mathrm{c}}\right.$ for length and site $=0$, site $=12.14$, base $=24.17$ ). Specifically, larger fish tended to have lower $\delta^{15} \mathrm{~N}$ values (slope of the relationship in the best model between length and $\delta^{15} \mathrm{~N}=-0.0097 \mathrm{~mm}^{-1}$; Fig. 5). Additionally, model comparison for $\delta^{13} \mathrm{C}$ suggests that there is some support for including length in a model that also has a site effect $\left(\Delta \mathrm{AIC}_{\mathrm{c}}\right.$ for length and site $=0$, base $=2.32$, site $=8.83$ ). In particular, larger fish had lower $\delta^{13} \mathrm{C}$ values, although support for this model is somewhat less than for $\delta^{15} \mathrm{~N}$ (slope of the relationship in the best model between length and $\delta^{13} \mathrm{C}=-0.0032 \mathrm{~mm}^{-1}$ ). This length and site model allows the intercept to vary across site and estimates a single slope parameter that describes the relationship between fish length and carbon isotopes.

The site effect was correlated with the location of the river. Specifically, using the site-specific intercept as the response variable and the rank order from west to east as the predictor variable, the $\delta^{15} \mathrm{~N}$ of sockeye from the west-side rivers of Bristol Bay (Togiak, Igushik, Nushagak and Wood) was more enriched than for sockeye returning to east-side rivers (Ugashik, Egegik, Naknek and Kvichak) (Spearman's rho $=-0.833, p=0.015)$. There was no such difference apparent in the $\delta^{13} \mathrm{C}$ of fish from these 2 sub-regions of Bristol Bay (Spearman's rho = 0.428, $\mathrm{p}=0.30$; Fig. 2, Table A2).

There was more variation for average $\delta^{15} \mathrm{~N}$ than for average $\delta^{13} \mathrm{C}$ observed across all rivers within a given year (Fig. 3). Furthermore, stable isotope data were more variable among rivers for the period between 1977 and 1989 compared with periods before and after this regime of the PDO (Figs. 2 \& 3). Separating data into periods of high and low salmon productivity associated with each of the PDO regimes produced only subtle changes in the mean isotope characteristics observed across all samples. The mean $( \pm \mathrm{SD})$ for $\delta^{15} \mathrm{~N}$ was $11.34 \pm 0.37 \%$ for the pre-regime shift (1964-1976), $11.49 \pm 0.63 \%$ for the high ocean productivity period (1979-1988) and $11.62 \pm 0.47 \%$ for the lower ocean productivity period (1991-2003). Over the same periods, changes in mean $\delta^{13} \mathrm{C}$ were larger than for $\delta^{15} \mathrm{~N}$, with means of $-16.72 \pm 0.26 \%$ for the pre-regime shift, $-17.30 \pm 0.44 \%$ for the high ocean productivity period and $-16.90 \pm 0.32 \%$ for the lower ocean productivity period.

PCA was used to reduce the dimensionality and extract common axes of variability in the stable isotope data. The first 2 principal components of the $\delta^{13} \mathrm{C}$ data explained 65.5 and $13.2 \%$ of the observed variation, respectively. $\mathrm{AIC}_{\mathrm{c}}$ model comparison indicated that carbon PC1 was best explained by summer wind mixing (JJmix) in the Bering Sea during the last year of growth in the ocean $(y=-235.1 x+$ $4.18, \mathrm{R}^{2}=0.45, \Delta \mathrm{AIC}_{\mathrm{c}}=0$; Fig. $6 \mathrm{~A}$, Table 1). The other environmental variables received substantially less support $\left(\Delta \mathrm{AIC}_{\mathrm{c}}>5\right.$; Table 1$)$. Carbon $\mathrm{PC} 2$ scores were best explained by SST in the southeastern Bering Sea during the last summer of growth $\left(y=-0.89 x+2.34, R^{2}=0.44, \Delta \mathrm{AIC}_{\mathrm{c}}=0\right.$; Fig. $6 \mathrm{~B}$, Table 1) and, to a lesser extent, NPI $\left(\mathrm{R}^{2}=0.34\right.$, $\left.\Delta \mathrm{AIC}_{\mathrm{c}}=2.31\right)$ and MEI $\left(\mathrm{R}^{2}=0.32, \Delta \mathrm{AIC}_{\mathrm{c}}=2.82\right.$; Table 1). Additionally, PC loadings indicated a correlation between rivers and individual principal components. Positive values indicated a positive 

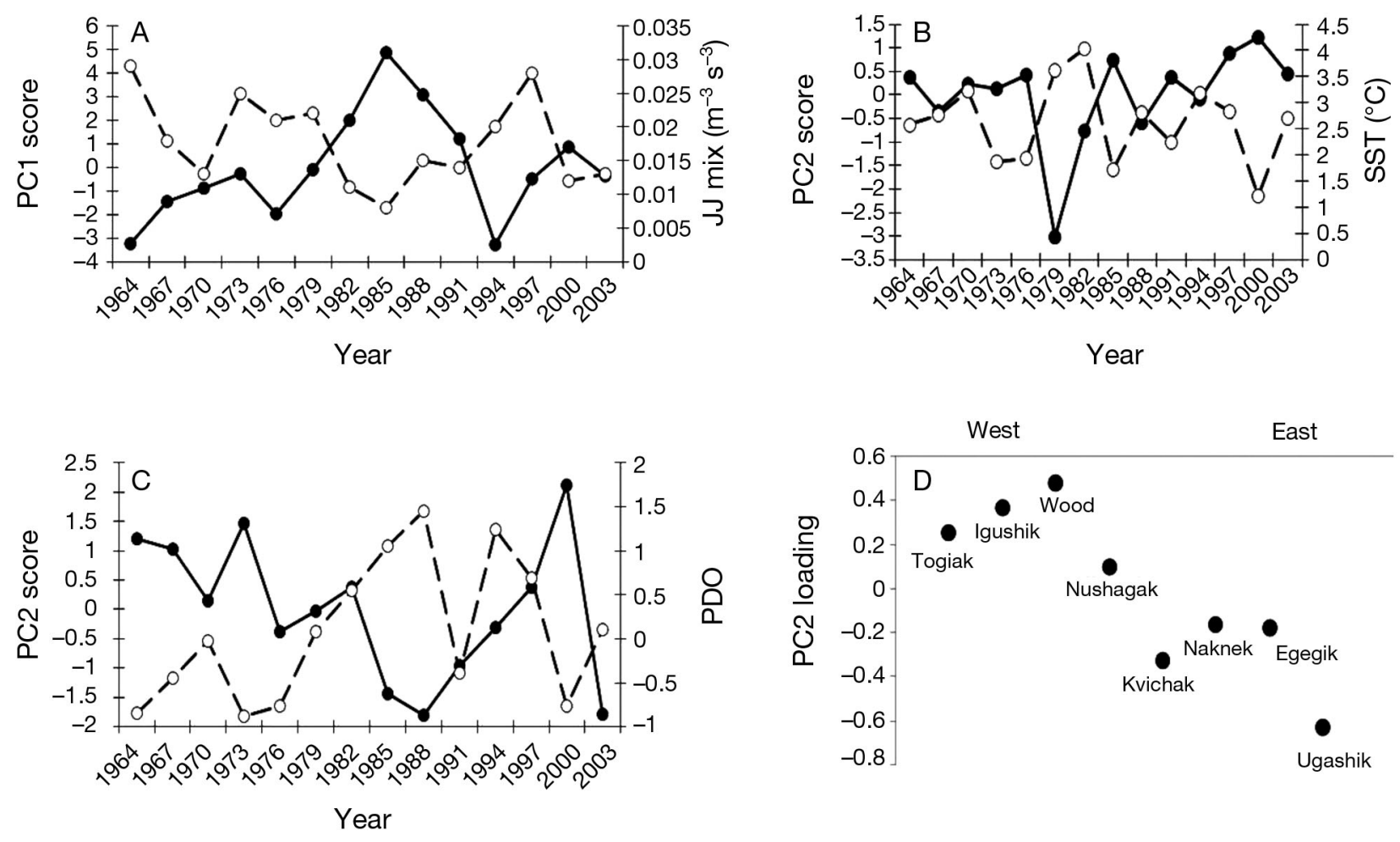

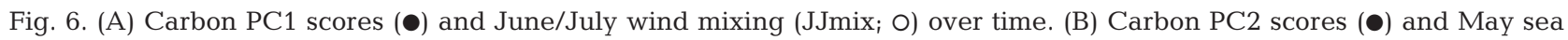
surface temperatures $\left(\mathrm{SST}_{;} \mathrm{O}\right)$ in the southeastern Bering Sea over time. (C) Nitrogen PC2 loading (๑) and the Pacific Decadal Oscillation (PDO; O) over time. (D) Loadings (rotation) of PC2 (carbon isotope data) according to east-west rank order of the rivers

association between the river and the PC whereas negative values indicated a negative association between the river and the PC. Carbon PC2 loadings were strongly associated with the geographic location of the rivers to which sockeye salmon returned, such that PC2 loadings were highly correlated with the east to west location of the river systems. Fish from rivers on the east side of Bristol Bay had negative loadings on PC2 whereas fish from west-side rivers had positive loadings on PC2. Rank location was significantly correlated with PC2 loading (Spearman's rho $=0.833, \mathrm{p}=0.015$; Fig. 6D).

PCA estimated that $40.5 \%$ of the $\delta^{15} \mathrm{~N}$ variance was explained by PC1 and $18.3 \%$ was explained by PC2.

Table 1. Relationships between oceanographic variables and sockeye salmon stable isotopes. We compared how well the first and second principle components from principle components analysis (PCA) were explained by 5 different oceanographic variables using Akaike's information criterion, corrected for small sample sizes $\left(\mathrm{AIC}_{\mathrm{c}}\right) . \Delta \mathrm{AIC}_{\mathrm{C}}$ is the relative support of the model in comparison to the other competing models, with lower $\Delta \mathrm{AIC}_{\mathrm{C}}$ values representing more support. Models with $\Delta \mathrm{AIC} \mathrm{C}_{\mathrm{C}}$ $>2$ have substantially less support. Factors are atmospheric-oceanographic variables used in the PCA. These factors are described in detail in 'Materials and methods' and include summer wind mixing (JJmix), Pacific Decadal Oscillation (PDO), North Pacific Index (NPI), sea surface temperature (SST) and El Niño-Southern Oscillation (MEI)

\begin{tabular}{|c|c|c|c|c|c|c|c|c|}
\hline \multirow[t]{2}{*}{ Factor } & \multicolumn{2}{|c|}{ Carbon - PC1 } & \multicolumn{2}{|c|}{ Carbon - PC2 } & \multicolumn{2}{|c|}{ Nitrogen - PC1 } & \multicolumn{2}{|c|}{ Nitrogen - PC2 } \\
\hline & $\mathrm{R}^{2}$ & $\Delta \mathrm{AIC}_{\mathrm{c}}$ & $\mathrm{R}^{2}$ & $\Delta \mathrm{AIC}_{\mathrm{c}}$ & $\mathrm{R}^{2}$ & $\Delta \mathrm{AIC}_{\mathrm{c}}$ & $\mathrm{R}^{2}$ & $\Delta \mathrm{AIC}_{\mathrm{c}}$ \\
\hline JJmix & 0.45 & 0 & 0.01 & 8.07 & 0.03 & 2.86 & 0.16 & 4.47 \\
\hline $\mathrm{PDO}$ & 0.18 & 5.62 & 0.03 & 7.78 & 0.21 & 0 & 0.39 & 0 \\
\hline NPI & 0.04 & 7.80 & 0.34 & 2.31 & 0 & 3.30 & 0.02 & 6.67 \\
\hline SST & 0.03 & 8.05 & 0.44 & 0 & 0.01 & 3.22 & 0.03 & 6.61 \\
\hline MEI & 0 & 8.45 & 0.32 & 2.82 & 0.03 & 2.89 & 0.16 & 4.61 \\
\hline
\end{tabular}


AIC model comparison indicated that nitrogen PC1 was best explained by PDO $\left(\mathrm{R}^{2}=0.21, \Delta \mathrm{AIC}_{\mathrm{c}}=0\right.$; Table 1), but this model was not significantly better than a null model that included no oceanographic variables $(p=0.10)$. All other models received less support and explained very little of the variance $\left(\mathrm{R}^{2}<\right.$ $\left.0.03, \Delta \mathrm{AIC}_{\mathrm{C}}>2\right)$. Nitrogen PC2 was best explained by PDO $\left(y=-0.94 x+0.07, \mathrm{R}^{2}=0.39, \Delta \mathrm{AIC}_{\mathrm{c}}=0\right)$, with other environmental variables receiving little support $\left(\Delta \mathrm{AIC}_{\mathrm{C}}>4 ;\right.$ Table 1, Fig. $\left.6 \mathrm{C}\right)$.

\section{DISCUSSION}

Comparisons of isotope values from salmon muscle tissue with that of scales consistently show that scales are enriched in $\delta^{13} \mathrm{C}$ relative to muscle tissue but $\delta^{15} \mathrm{~N}$ is not significantly different between the 2 tissues (Satterfield \& Finney 2002, Trueman et al. 2005, Trueman \& Moore 2007, D. E. Schindler unpubl. data). Scale $\delta^{13} \mathrm{C}$ is enriched by 2.2 to $4.0 \%$ relative to muscle (Satterfield \& Finney 2002, Sinnatamby et al. 2008). Our results showed enriched $\delta^{13} \mathrm{C}$ values and similar $\delta^{15} \mathrm{~N}$ values in scales relative to those found in studies of muscle stable isotopes (Satterfield \& Finney 2002, Johnson \& Schindler 2009). Additionally, carbon and nitrogen stable isotope values showed similar variability to previously published studies for sockeye salmon (as reviewed by Johnson \& Schindler 2009). Thus, archived fish scales can provide a valuable resource for retrospective stable isotope analyses.

We assessed the variation among rivers in the carbon and nitrogen stable isotope characteristics of Bristol Bay sockeye salmon scales over a period (1964-2003) during which large changes in oceanographic conditions occurred in the North Pacific Ocean. Our results suggested that (1) stable isotope values were remarkably consistent over the study period, despite substantial changes in salmon production and oceanographic conditions in this region; (2) there were river-specific patterns in the variation of stable isotopes through time; (3) stable isotopes tended to be negatively related to fish size; (4) $\delta^{15} \mathrm{~N}$ and $\delta^{13} \mathrm{C}$ were related to the location (river) of stock origin; (5) isotopic characteristics among rivers were more variable during the period of high ocean productivity (after the 1977 regime shift and before the 1989 regime shift); and (6) some of the dominant signals in stable isotope variation were related to important environmental physical processes; however, they appear to be significantly correlated with the isotopic characteristics of individual stocks in different ways.

\section{Stable isotope variability}

Salmon carbon and nitrogen stable isotope signatures were variable through time and across stocks (Fig. 2). For example, average $\delta^{15} \mathrm{~N}$ for individuals in a year varied by almost $3 \%$ in a given river system over time (Fig. 2). Furthermore, stocks showed different trajectories of change through time (Table A2). The study period was characterized by substantial changes in climate and ocean conditions in the North Pacific and the Bering Sea. A large-scale climate shift in 1977 resulted in a reorganization of the associated communities (from zooplankton to top predators), profoundly affecting the trophic structure of Gulf of Alaska and Bering Sea food webs (Anderson \& Piatt 1999, Hare \& Mantua 2000, Conners et al. 2002). Concurrent with this shift in marine communities and climate regime, the production of Alaska salmon doubled during the 1976-1988 period (Mantua et al. 1997). Given the magnitude of change in salmon production during the last 4 decades, it is surprising that stable isotope signatures were so invariant through this time period (Figs. 2 \& 3). One explanation is that during the reorganization of marine communities, salmon prey (such as zooplankton) were released from predation by a decrease in predators (such as capelin) and became more abundant, allowing salmon to thrive and increase in abundance. Alternatively, sockeye salmon may be extremely opportunistic across space, time and prey types in ways that produce relatively invariant stable isotope distributions.

Most species of Pacific salmon are opportunistic and omnivorous predators that feed on a wide variety of pelagic prey, including copepods, amphipods, euphausiids, squid, decapod larvae, pteropods, gelatinous plankton such as ctenophores and jellyfish, and small fishes (LeBrasseur 1966, Pearcy et al. 1988, Brodeur 1990, Davis 2003). This broad array of potential prey theoretically allows individuals or populations of salmon to shift diet in response to changing prey distribution and abundances caused by changing ocean conditions or in response to intra- and inter-specific competition for prey resources (Tadokoro et al. 1996, Walker et al. 1998, Anderson \& Piatt 1999, Ruggerone et al. 2003). The limited variation in the stable isotope data presented here, particularly for $\delta^{15} \mathrm{~N}$, emphasizes the opportunistic foraging strategies of sockeye salmon across space and time and suggests that salmon adapt foraging preferences across the variation in prey they certainly encounter in the marine environment. 


\section{Stable isotopes in salmon prey}

Carbon and nitrogen stable isotopes are a useful tool in the study of trophic ecology, with some caveats. Carbon stable isotopes are useful for revealing the source of production in a food web (Peterson \& Fry 1987, France 1995) and can be used to broadly distinguish between foraging in pelagic versus benthic habitats (McConnaughey \& McRoy 1979, Fry \& Sherr 1984, Duggins et al. 1989, Hobson et al. 1994), but are perhaps less useful for determining smallscale differences in feeding location (Schell et al. 1998). Nitrogen stable isotopes reflect the combined effects of the physiology and trophic ecology of the consumer as well as the biogeochemistry of the ecosystem in which the consumer is foraging (Cabana \& Rasmussen 1996, Vander Zanden \& Rasmussen 1999, Post 2002). To make inferences about variation in foraging strategies and migration patterns of consumers, it is necessary to know the isotopic values of the basal food web where the consumer feeds (Vander Zanden \& Rasmussen 1999, Post 2002). These values vary in space and time and are very difficult to obtain for highly migratory species such as Pacific salmon, which spend multiple years foraging in the spatially and temporally heterogeneous ocean.

Although a time series of sockeye prey or POM isotope data does not exist, we compiled several data sets from the existing literature and unpublished data across different years that can give some basic information on baseline isotope signatures for the geographic range of the sockeye salmon in our study (Fig. 4). Although spatially and temporally limited, prey and POM isotope composition was highly variable compared with that observed in sockeye salmon over this time period (Fig. 4). The low level of variation in stable isotope composition of sockeye salmon compared to the variation observed in their prey emphasizes our conclusion that sockeye salmon feed opportunistically and broadly across the prey items available in their communities of the North Pacific Ocean.

\section{Stable isotopes and fish size}

Nitrogen stable isotopes varied among rivers and were negatively related to the average length of the fish (Fig. 5). Conversely, carbon stable isotopes did not vary by river location but were marginally related to fish size (Fig. 5). Salmonids tend to swallow their prey whole (Hart 1997) and thus can show a strong positive relationship between body size and trophic position (Romanuk et al. 2011). Thus, if $\delta^{15} \mathrm{~N}$ values were driven by trophic position alone, we should expect a positive relationship between fish size and $\delta^{15} \mathrm{~N}$. That we saw a negative relationship suggested that variation in nitrogen isotopes may have been related to foraging location and driven by nitrogen sources at the base of the food web, rather than reflecting a trophic difference. In particular, nearshore habitats tend to support prey with enriched $\delta^{15} \mathrm{~N}$ and $\delta^{13} \mathrm{C}$ compared with offshore habitats (Hobson et al. 1994, Schell et al. 1998). Thus, the relationship between fish size and their stable isotopes suggests that larger fish may forage in habitat further offshore than their smaller counterparts; this is corroborated by high seas data (e.g. Farley et al. 2007).

\section{Stable isotopes and climate shifts}

Salmon production shows a significant response to large-scale climate regime shifts (Mantua et al. 1997). In particular, Alaska sockeye salmon production was strongly coherent with inter-decadal shifts in the PDO (Hare et al. 1999, Hare \& Mantua 2000). Stable isotope data presented here also demonstrated a relationship to climate regime shifts, but the magnitude of variation was small, and the most prominent signal was an increase in variation in the isotope signatures among rivers (Figs. 2 \& 3). Stable isotope data were most variable between the 1977 and 1989 regime shifts during the period of time of high ocean productivity. Specifically, the standard deviations for $\delta^{15} \mathrm{~N}$ and $\delta^{13} \mathrm{C}$ were 0.37 and 0.26 , respectively, prior to $1977,0.47$ and 0.32 after the 1989 regime shift, and 0.63 and 0.44 between the 2 regime shifts (Fig. 3). Thus, salmon isotope characteristics, and presumably their foraging strategies (in terms of prey selection or spatial distributions), were more variable among rivers during the period of high ocean productivity in the North Pacific Ocean and the Bering Sea. Again, this result supports the general notion of the opportunistic foraging and migratory abilities of sockeye salmon in response to a high diversity of prey items and intra- and inter-specific competition (Kaeriyama et al. 2004).

In large ecosystems such as the Bering Sea or the North Pacific Ocean where sockeye salmon migrate and feed, there are several mechanisms that could cause changes in isotopic ratios across both space and time. Isotope ratios can be driven from the top down (e.g. by in consumer prey selection) or from the bottom up (e.g. by changes in isotopic baselines driven by the geochemistry and nutrient cycling of the 
ecosystem). Thus, differences in consumer isotopic ratios may be driven by several factors, including (1) the physiology of the consumer (such as body size, age or growth rate), (2) changes in target prey trophic level, (3) changes in the isotopic values of prey items resulting from prey items themselves shifting foraging trophic level and (4) changes in isotopic signatures at the base of the food web driving isotopic differences from the bottom up. Given that carbon isotopes are coherent and nitrogen isotopes were more variable among rivers over time, we speculate that there was some trophic partitioning among prey resources or feeding locations between populations, especially after the 1977 regime shift (Fig. 2).

\section{Stable isotopes and physical oceanographic indices}

Large-scale changes in climate have been shown to have broad effects on the ecology of the North Pacific Ocean and the Bering Sea (Francis et al. 1998, Anderson \& Piatt 1999, Benson \& Trites 2002). Although the specific mechanisms producing biological responses to climate changes are not well described, there is evidence supporting bottom-up processes transmitted through the food web via phytoplankton productivity (Polovina et al. 1994, McGowan et al. 1998, Brodeur et al. 1999). Our results showed a relationship between sockeye salmon stable isotopes and certain climate and physical oceanographic indices (Table 1). Among populations, $\delta^{13} \mathrm{C}$ was remarkably consistent across the period of study (Fig. 2). Bristol Bay sockeye show stock-specific marine distributions (Habicht et al. 2010) and thus are in different locations at a given time. The similarity in carbon isotopes across stocks suggests that although stocks may be spatially separated, they appear to be foraging on similar marine food. Although changes in $\delta^{13} \mathrm{C}$ through time could be due to either a change in carbon sources at the base of the food web or a synchronous change in foraging location for all stocks, we hypothesize that the changes through time in $\delta^{13} \mathrm{C}$ were likely due to changes in the baseline signatures of the prey items as ocean productivity changed in response to climate shifts (Mantua et al. 1997, Anderson \& Piatt 1999). The strong relationships between the carbon isotope PC scores and marine climate indices suggest that physical forcing played a strong role in the primary productivity at the base of the marine food web, e.g. via changes in primary productivity itself or changes in carbon sources.

The principal components that explained the majority of nitrogen stable isotope variability were less related to climate indices than the carbon prin- cipal components (Table 1). PC1 explained $40.5 \%$ of the variation in nitrogen isotopes and had no significant relationship to any of the climate indices that were tested (Table 1). PC2 explained $18.3 \%$ of the variance for $\delta^{15} \mathrm{~N}$. Nitrogen PC2 scores were inversely related to $\mathrm{PDO}$, suggesting that either sockeye prey selectivity changed in association with PDO shifts or the food web changed fundamentally post-regime shift (after 1977).

\section{Stock-specific patterns}

There were stock-specific patterns to nitrogen and, to a lesser extent, carbon stable isotope data. Linear mixed-effect modeling suggested that nitrogen isotopes were related to river of origin whereas carbon isotopes were not (Fig. 2). Specifically, there was a spatial pattern to the $\delta^{15} \mathrm{~N}$ values of fish such that east-side rivers tended to be more enriched (for a given length of fish) than west-side rivers. In contrast, PCA showed a spatial pattern in the carbon isotope data for each of the major sockeye salmon stocks. The carbon PC2 loadings, though accounting for a small proportion of the variance in $\delta^{13} \mathrm{C}$, were strongly associated with the east/west spatial arrangement of the rivers in Bristol Bay (Fig. 6D). East-side rivers had negative loadings on PC2 whereas west-side rivers had positive associations with PC2. This result suggests that different sockeye salmon stocks partition the ocean according to either feeding preferences or the locations of feeding areas. Although these rivers are termed 'east-side' and 'west-side' rivers for the purposes of this paper, there is also a latitudinal difference between the 2 areas. Latitudinal gradients of marine carbon and nitrogen stable isotopes occur, although not necessarily in concurrent patterns (Schell et al. 1998, S. P. Johnson unpubl. data). High seas tagging studies have suggested that migration and distribution patterns differ between northwestern and southeastern Bristol Bay sockeye salmon stocks (Rogers 1986, 1988, Habicht et al. 2010). Northwestern Bristol Bay stocks are more likely to be distributed in the Gulf of Alaska in association with smolt migration timing than southeastern Bristol Bay stocks (Rogers 1986, 1988). Recent genetic studies have also shown differences in distribution between southeastern and northwestern Bristol Bay stocks, with southeastern stocks distributed farther to the north and west in the Bering Sea than the northwestern stocks, which are distributed farther to the south and east (Habicht et al. 2010). Variation in stable isotopes according to body size and 
the location of stock origin suggests that there are differences in basal food web primary productivity or shifts in prey trophic position or foraging location (McClelland \& Montoya 2002, Olson et al. 2010). Without thorough investigations of isotopic variability of basal food web and prey resources, it is difficult to distinguish between the factors causing variation in the stable isotope characteristics of Bristol Bay sockeye salmon.

\section{CONCLUSIONS}

Catch records for Bristol Bay sockeye salmon show substantial interannual variation in the production of different stocks over time (Hilborn et al. 2003, Schindler et al. 2010). In other words, populations of Bristol Bay sockeye do not respond coherently to regional environmental variation (Hilborn et al. 2003, Rogers \& Schindler 2008). This asynchrony buffers the fishery from environmental variability (Schindler et al. 2010). Although the specific mechanisms underlying such 'biocomplexity' are poorly understood, it has been thought to this point that much of the variability stems from freshwater processes (Hilborn et al. 2003). However, the present study suggests that there is a marine component to the biocomplexity of sockeye salmon stocks as well. Whether the mechanism is spatial or trophic differentiation in foraging strategies, stable isotope data demonstrated differences among populations over time. Substantial effort is currently being directed at developing ecosystem models of the North Pacific to understand how climate change will affect its community and ecosystem services. We suggest that a marine component to biocomplexity for sockeye salmon may also be important to the reliability of the overall stock complex and should be considered when modeling responses of Bristol Bay sockeye salmon to ongoing climate change.

Acknowledgements. This research was made possible by funding provided by the Gordon and Betty Moore Foundation, and the National Science Foundation (Biocomplexity and Biological Oceanography). We are indebted to L. Fair and F. West of the Alaska Department of Fish and Game for providing access to archived sockeye salmon scales, and N. Davis and the crew of the RV 'Wakatake maru' for sampling copepods and amphipods. We thank B. Rogers (UW Alaska Salmon Program) for laboratory assistance and D. Wilbur (UW Oceanography) for mass spectrometer isotopic analysis of scales. We also thank P. Woods, J. Olden, J. Moore and A. Strecker for useful advice on the multivariate analyses, and J. Moore and L. Fair for comments on an earlier version of the manuscript.

\section{LITERATURE CITED}

Anderson PJ, Piatt JF (1999) Community reorganization in the Gulf of Alaska following ocean climate regime shift. Mar Ecol Prog Ser 189:117-123

Aydin KY, McFarlane GA, King JR, Megrey BA, Myers KW (2005) Linking oceanic food webs to coastal production and growth rates of Pacific salmon (Oncorhynchus spp.), using models on three scales. Deep-Sea Res II 52: $757-780$

Beamish RJ, Noakes DJ, McFarlane GA, Klyashtorin L, Ivanov VV, Kurashov V (1999) The regime concept and natural trends in the production of Pacific salmon. Can J Fish Aquat Sci 56:516-526

Benson AJ, Trites AW (2002) Ecological effects of regime shifts in the Bering Sea and the eastern North Pacific. Fish Fish 3:95-113

Brodeur RD (1990) A synthesis of the food habits and feeding ecology of salmonids in marine waters of the North Pacific. INPFC Doc. FRI-UW-9016. Fisheries Research Institute, University of Washington, Seattle, WA

Brodeur RD, Mills CE, Overland JE, Schumacher JD (1999) Evidence for a substantial increase in gelatinous zooplankton in the Bering Sea, with possible links to climate change. Fish Oceanogr 8:296-306

Burnham KP, Anderson DR (2002) Model selection and multimodel inference. Springer, New York, NY

Cabana G, Rasmussen JB (1996) Comparison of aquatic food chains using nitrogen isotopes. Proc Natl Acad Sci USA 93:10844-10847

Clark JH, McGregor A, Mecum RD, Krasnowski P, Carroll AM (2006) The commercial fishery in Alaska. Alaska Fish Res Bull 12:1-146

Conners ME, Hollowed AB, Brown E (2002) Retrospective analysis of Bering Sea bottom trawl surveys: regime shift and ecosystem organization. Prog Oceanogr 55:209-222

Davis ND (2003) Feeding ecology of Pacific salmon (Oncorhynchus spp.) in the central North Pacific Ocean and central Bering Sea, 1991-2000. PhD dissertation, Hokkaido University, Hakodate

> Duggins DO, Simenstad CA, Estes JA (1989) Magnification of secondary production by kelp detritus in coastal marine ecosystems. Science 245:170-173

Farley EV, Murphy JM, Atkinson M, Eisner L (2007) Juvenile sockeye salmon distribution, size, condition and diet in years with warm and cool spring sea temperatures along the eastern Bering shelf. J Fish Biol 71:1145-1158

- France RL (1995) Carbon-13 enrichment in benthic compared to planktonic algae: foodweb implications. Mar Ecol Prog Ser 124:307-312

- Francis RC, Hare SR, Hollowed AB, Wooster WS (1998) Effects of interdecadal climate variability on the oceanic ecosystems of the NE Pacific. Fish Oceanogr 7:1-21

Fry B, Sherr EB (1984) ${ }^{13} \mathrm{C}$ measurements as indicators of carbon flow in marine and fresh-water ecosystems. Contrib Mar Sci 27:13-47

> Guo L, Tanaka T, Wang D, Tanaka N, Murata A (2004) Distributions, speciation and stable isotope composition of organic matter in the southeastern Bering Sea. Mar Chem 91:211-226

> Habicht C, Seeb L, Myers KW, Farley EV, Seeb J (2010) Summer-fall distribution of stocks of immature sockeye salmon in the Bering Sea as revealed by singlenucleotide polymorphisms. Trans Am Fish Soc 139: 1171-1191 
Hare SR, Francis RC (1995) Climate change and salmon production in the northeast Pacific Ocean. In: Beamish RJ (ed) Climate change and northern fish populations. Can Spec Pub Fish Aquat Sci 121:357-372

Hare SR, Mantua NJ (2000) Empirical evidence for North Pacific regime shifts in 1977 and 1989. Prog Oceanogr 47: 103-145

> Hare SR, Mantua NJ, Francis RC (1999) Inverse production regimes: Alaska and West Coast Pacific salmon. Fisheries 24:6-14

Hart PJB (1997) Foraging tactics. In: Godin JJ (ed) Behavioural ecology of teleost fishes. Oxford University Press, Oxford, p 104-133

> Hilborn R, Quinn TP, Schindler DE, Rogers DE (2003) Biocomplexity and fisheries sustainability. Proc Natl Acad Sci USA 100:6564-6568

> Hilderbrand GV, Schwartz CC, Robbins CT, Jacoby ME, Hanley TA, Arthur SM, Servheen C (1999) The importance of meat, particularly salmon, to body size, population productivity, and conservation of North American brown bears. Can J Zool 77:132-138

> Hirons AC, Schell DM, St Aubin DJ (2001) Growth rates of vibrissae of harbor seals (Phoca vitulina) and Steller sea lions (Eumetopias jubatus). Can J Zool 79:1503-1601

> Hobson KA, Piatt JF, Pitocchelli J (1994) Using stable isotopes to determine seabird trophic relationships. J Anim Ecol 63:786-798

> Hutchinson JJ, Trueman CN (2006) Stable isotope analyses of collagen in fish scales: limitations set by scale architecture. J Fish Biol 69:1874-1880

> Johnson SP, Schindler DE (2009) Trophic ecology of Pacific salmon (Oncorhynchus spp.) in the ocean: a synthesis of stable isotopes research. Ecol Res 24:855-863

Kaeriyama M, Nakamura M, Edpalina R, Bower JR, Yamaguchi H, Walker RV, Myers KW (2004) Changes in feeding ecology and trophic dynamics of Pacific salmon (Oncorhynchus spp.) in the central Gulf of Alaska in relation to climate events. Fish Oceanogr 13:197-207

Kalnay E, Kanamitsu M, Kistler R, Collins W and others (1996) The NCEP/NCAR 40-year reanalysis project. Bull Am Meteorol Soc 77:437-471

LeBrasseur RJ (1966) Stomach contents of salmon and steelhead trout in the northeastern Pacific Ocean. J Fish Res Board Can 23:85-100

Mantua NJ, Hare SR, Zhang Y, Wallace JM, Francis RC (1997) A Pacific interdecadal climate oscillation with impacts on salmon production. Bull Am Meteorol Soc 78:1069-1079

> McClelland JW, Montoya JP (2002) Trophic relationships and the nitrogen isotopic composition of amino acids in plankton. Ecology 83:2173-2180

> McConnaughey T, McRoy CP (1979) Food-web structure and the fractionation of carbon isotopes in the Bering Sea. Mar Biol 53:257-262

McGowan JA, Cayan DR, Dorman LM (1998) Climate-ocean variability and ecosystem response in the northeast Pacific. Science 281:210-216

Mueter FJ, Ware DM, Peterman RM (2002) Spatial correlation patterns in coastal environmental variables and survival rates of salmon in the north-east Pacific Ocean. Fish Oceanogr 11:205-218

Myers KW, Klovach NV, Gritsenko OF, Urawa S, Royer TC (2007) Stock-specific distributions of Asian and North American salmon in the open ocean, interannual changes, and oceanographic conditions. N Pac Anad Fish Comm Bull 4:159-177
Olson RJ, Popp BN, Graham BS, Lopez-Ibarra GA and others (2010) Food-web inferences of stable isotope spatial patterns in copepods and yellowfin tuna in the pelagic eastern Pacific Ocean. Prog Oceanogr 86:124-138

- Pearcy WG, Schoener A (1987) Changes in the maritime biota coincident with the 1982-1983 El Niño in the Northeastern Subarctic Pacific Ocean. J Geophys Res 92: 14417-14428

Pearcy WG, Brodeur RD, Shenker JM, Smoker WW, Endo Y (1988) Food habits of Pacific salmon and steelhead trout, midwater trawl catches and oceanographic conditions in the Gulf of Alaska, 1980-1985. Bull Ocean Res Inst Univ Tokyo 26:29-78

Peterson BJ, Fry B (1987) Stable isotopes in ecosystem studies. Annu Rev Ecol Syst 18:293-320

Polovina JJ, Mitchum GT, Graham NE, Craig MP, DeMartini EE, Flint EN (1994) Physical and biological consequences of a climate event in the central North Pacific. Fish Oceanogr 3:15-21

> Post DM (2002) Using stable isotopes to estimate trophic position: models, methods, and assumptions. Ecology 83: 703-718

> Pyper BJ, Mueter FJ, Peterman RM (2005) Across-species comparisons of spatial scales of environmental effects on survival rates of northeast Pacific salmon. Trans Am Fish Soc 134:86-104

Quinn TP (2005) The behavior and ecology of Pacific salmon and trout. University of Washington Press, Seattle, WA

R Core Development Team (2011) R: a language and environment for statistical computing. R Foundation for Statistical Computing, Vienna

Rogers DE (1986) Pacific salmon. In: Hood DW, Zimmerman ST (eds) The Gulf of Alaska: physical environment and biological resources. National Oceanic and Atmospheric Administration, Washington, DC, p 461-476

Rogers DE (1988) Bristol Bay smolt migrations: timing and size composition and the effects on distribution and survival at sea. In: McNeil WJ (ed) Salmon production, management, and allocation: biological, economic, and policy issues. Oregon State University Press, Corvallis, OR, p 87-101

Rogers LA, Schindler DE (2008) Asynchrony in population dynamics of sockeye salmon in southwest Alaska. Oikos 117:1578-1586

> Rogers LA, Schindler DE (2011) Scale and the detection of climatic influences on the productivity of salmon populations. Glob Change Biol 17:2546-2558

Romanuk TN, Hayward A, Hutchings JA (2011) Trophic level scales positively with body size in fishes. Glob Ecol Biogeogr 20:231-240

> Ruggerone GT, Zimmermann M, Myers KW, Nielsen JL, Rogers DE (2003) Competition between Asian pink salmon (Oncorhynchus gorbuscha) and Alaskan sockeye salmon (O. nerka) in the North Pacific Ocean. Fish Oceanogr 12:209-219

> Satterfield FR, Finney BP (2002) Stable isotope analysis of Pacific salmon: insight into trophic status and oceanographic conditions over the last 30 years. Prog Oceanogr 53:231-246

> Schell DM, Saupe SM, Haubenstock N (1989) Bowhead whale (Balena mysticetus) growth and feeding as estimated by $\delta^{13} \mathrm{C}$ techniques. Mar Biol 103:433-443

Schell DM, Barnett BA, Vinette KA (1998) Carbon and nitrogen isotope ratios in zooplankton of the Bering, Chukchi, and Beaufort seas. Mar Ecol Prog Ser 162:11-23 
Schindler DE, Hilborn R, Chasco B, Boatright CP, Quinn TP, Rogers LA, Webster MS (2010) Population diversity and the portfolio effect in an exploited species. Nature 465: 609-612

Shaw PJA (2003) Multivariate statistics for the environmental sciences. Oxford University Press, New York

Sinnatamby RN, Dempson BJ, Power M (2008) A comparison of muscle- and scale-derived $\delta^{13} \mathrm{C}$ and $\delta^{15} \mathrm{~N}$ across three life-history stages of Atlantic salmon, Salmo salar. Rapid Commun Mass Spectrom 22:2773-2778

Smith SL, Henrichs SM, Rho T (2002) Stable C and N isotopic composition of sinking particles and zooplankton over the southeastern Bering Sea shelf. Deep-Sea Res II 49:6031-6050

Tadokoro K, Ishida Y, Davis ND, Ueyanai S, Sugimoto T (1996) Change in chum salmon (Oncorhynchus keta) stomach contents associated with fluctuation of pink salmon (O. gorbuscha) abundance in the central subarctic Pacific and Bering Sea. Fish Oceanogr 5:89-99

Trenberth KE, Hurrell JW (1994) Decadal atmosphereocean variations in the Pacific. Clim Dyn 9:303-313

Trueman CN, Moore A (2007) Use of the stable isotope composition of fish scales for monitoring aquatic ecosuystems In: Dawson TE, Siegwolf RTW (eds) Stable isotopes as indicators of ecological change. Elsevier, Oxford, p 145-161
Trueman CN, McGill RAR, Guyard PH (2005) The effect of growth rate on tissue-diet isotopic spacing in rapidly growing animals. An experimental study with Atlantic salmon (Salmo salar). Rapid Commun Mass Spectrom 19: 3239-3247

Vander Zanden MJ, Rasmussen JB (1999) Primary consumer $\delta^{15} \mathrm{~N}$ and $\delta^{13} \mathrm{C}$ and the trophic position of aquatic consumers. Ecology 80:1395-1404

> Vander Zanden MJ, Chandra S, Allen BC, Rueter JE, Goldman CR (2003) Historical food web structure and restoration of native aquatic communities in the lake Tahoe (California-Nevada) basin. Ecosystems 6:274-288

Walker RV, Myers KW, Ito S (1998) Growth studies from 1956-95 collections of pink and chum salmon scales in the North Pacific Ocean. N Pac Anad Fish Comm Bull 1: 54-65

- Welch DW, Parsons TR (1993) ${ }^{13} \mathrm{C}$ and ${ }^{15} \mathrm{~N}$ values as indicators of trophic position and competitive overlap for Pacific salmon (Oncorhynchus spp.). Fish Oceanogr 2: $11-23$

Wolter K, Timlin MS (1998) Measuring the strength of ENSO-how does 1997/98 rank? Weather 53:315-324

Yeakel JD, Patterson BD, Fox-Dobbs K, Okumura MM and others (2009) Cooperation and individuality among man-eating lions. Proc Natl Acad Sci USA 106: 19040-19043

Appendix 1. Sockeye scale stable isotope data by year and by river

Table A1. Means and standard deviations (SD) for carbon and nitrogen stable isotope data for each year averaged for all Bristol Bay rivers included in this study. Data are from $\mathrm{n}=$ 15 sockeye salmon scales per sample year

\begin{tabular}{|ccccc|}
\hline \multirow{2}{*}{ Year } & \multicolumn{2}{c}{$\delta^{15} \mathrm{~N}$} & \multicolumn{2}{c|}{$\delta^{13} \mathrm{C}$} \\
& Mean & SD & Mean & SD \\
\hline 1964 & 11.67 & 0.30 & -16.49 & 0.24 \\
1967 & 11.28 & 0.20 & -16.74 & 0.24 \\
1970 & 11.39 & 0.35 & -16.83 & 0.18 \\
1973 & 11.26 & 0.44 & -16.89 & 0.19 \\
1976 & 11.10 & 0.34 & -16.67 & 0.27 \\
1979 & 11.08 & 0.38 & -16.93 & 0.49 \\
1982 & 11.55 & 0.59 & -17.24 & 0.26 \\
1985 & 11.71 & 0.76 & -17.63 & 0.31 \\
1988 & 11.62 & 0.62 & -17.41 & 0.34 \\
1991 & 11.37 & 0.31 & -17.14 & 0.22 \\
1994 & 11.98 & 0.53 & -16.52 & 0.25 \\
1997 & 11.58 & 0.35 & -16.90 & 0.19 \\
2000 & 11.84 & 0.30 & -17.05 & 0.28 \\
2003 & 11.33 & 0.51 & -16.90 & 0.26 \\
\hline
\end{tabular}

Editorial responsibility: Yves Cherel, Villiers-en-Bois, France
Table A2. Mean stable isotope values and SD for Bristol Bay rivers included in this study from 1964 to 2003. East-side rivers are in italics. Data are from $\mathrm{n}=210$ sockeye salmon scales per river

\begin{tabular}{|lcccc|}
\hline \multirow{2}{*}{ River } & \multicolumn{2}{c}{$\delta^{15} \mathrm{~N}$} & \multicolumn{2}{c|}{$\delta^{13} \mathrm{C}$} \\
& Mean & SD & Mean & SD \\
\hline Togiak & 11.65 & 0.25 & -16.93 & 0.48 \\
Igushik & 11.45 & 0.43 & -16.85 & 0.55 \\
Nushagak & 11.64 & 0.57 & -16.85 & 0.37 \\
Wood & 12.04 & 0.54 & -17.21 & 0.31 \\
Ugashik & 11.21 & 0.42 & -16.85 & 0.35 \\
Egegik & 11.21 & 0.33 & -16.91 & 0.39 \\
Naknek & 11.42 & 0.53 & -16.94 & 0.24 \\
Kvichak & 11.24 & 0.29 & -17.06 & 0.46 \\
\hline
\end{tabular}

Submitted: October 29, 2011; Accepted: April 18, 2012 Proofs received from author(s): July 13, 2012 